\title{
Scale morphology of Prochilodus lineatus with emphasis on the scale epithelium
}

\author{
Alves, RMS $^{a}{ }^{*}$, Pereira, BF. ${ }^{a}$, Pitol, DL. ${ }^{b}$, Senhorini, JA. ${ }^{c}$, Alcântara-Rocha, $R C G .^{c}$ \\ and Caetano, $\mathrm{FH}^{a}$ \\ ${ }^{a}$ Universidade Estadual Paulista "Júlio de Mesquita Filho", Instituto de Biociências, \\ Campus de Rio Claro, Av. 24A, 1515, Bela Vista, CEP 13506-900, Rio Claro, SP, Brazil \\ ${ }^{b}$ Faculdade de Odontologia, Univesidade de São Paulo - USP, Ribeirão Preto, SP, Brazil \\ ${ }^{c}$ Laboratório de Reprodução de Peixes - ICMBio/CEPTA, Pirassununga, SP, Brazil \\ *e-mail: beka_msa@hotmail.com
}

Received April 4, 2012 - Accepted August 23, 2012-Distributed August 31, 2013

(With 1 figure)

\begin{abstract}
The fish body is entirely covered by a thin, smooth and glandular epidermis, closely attached to the scales inserted on the dermis. The descriptive work on this tissue dates to twenty or thirty years ago, bears very little photographic record and does not focus on the scale epithelium, despite the fact that it is in direct contact with the environment. Thereupon, the present study characterizes the scale epithelium of Prochilodus lineatus, a robust species of fish. The observations show that the scale is completely covered by epithelium thicker on the proximal end of the scale, multilayered on the dorsal surface and undifferentiated on the ventral surface, and covered by mucous producing cells, mostly acid mucous. The scale is formed by plywood-like collagen matrix of collagen type III and supported by a network of elastic fibers on the ventral face. Differentiated cellular types are present, such as club cells, considered to be responsible for the release of alarm substances, which suggests possible use in environmental assessment as a non-invasive technique.
\end{abstract}

Keywords: curimbatá, morphology, scale, epithelium.

\section{Morfologia da escama de Prochilodus lineatus com ênfase no epitélio da escama}

\section{Resumo}

O corpo dos peixes é inteiramente coberto por uma epiderme fina, lisa e grandular intimamente aposta às escamas inseridas na derme. Os trabalhos descritivos sobre este assunto datam de vinte ou trinta anos atrás e possuem pouco registro fotográfico, além de não se focarem no epitélio da escama, apesar do fato de este estar em contato direto com o ambiente. Portanto, o presente estudo pretende caracterizar o epitélio das escamas de Prohilodus lineatus, uma espécie de peixe robusto. As observações mostram que a escama é completamente recoberta por epitélio, mais grosso na extremidade proximal da escama, estratificado na superfície dorsal, indiferenciado na superfície ventral e coberto por células mucosas, principalmente de muco de ácido. A escama é formada por uma matriz de colágeno de estrutura semelhante a madeira compensada de colágeno tipo III e se apóia em uma rede de fibras elásticas na superfície ventral. Tipos celulares diferenciados são presentes, como células "club", consideradas responsáveis pela liberação de substâncias de alarme, o que sugere possível uso como técnica não invasiva para monitoramento ambiental.

Palavras-chave: curimbatá, morphology, scale, epithelium.

\section{Introduction}

Members of the Amiiformes Order, in which the Infraclass Teleostei is found, generally carry cycloid scales (Storer et al., 2007). The cycloid scales are subcircular, disc-shaped and thin (Panfili et al., 2002). These scale's growth accompanies the fish's growth and as a consequence, in many species it determines the appearance of a series of concentric rings on the margin of the scales (circulli) (Orr, 1908; Storer et al., 2007). Because of these structures, scales are commonly used to determine the age of fish (Panfili et al., 2002).
Recent literature indicates there is no renewal of that integument, although occasionally scales can be lost and replaced (Storer et al., 2007).

According to Storer et al. (2007) the body of most fish is also entirely covered by a thin, smooth and glandular epidermis, juxtaposed to the scales inserted in the dermis. According to the same author, the body and the tail carry overlapping dermal scales arranged on longitudinal and diagonal rows. Each scale is inserted on a dermal pocket, grows during the animal's life and is covered by a thin layer of skin on the portion outside of the dermal 
pocket. (Panfili et al., 2002; Storer et al., 2007). They consist of a collagen matrix covered by calcium salts. The calcification process occurs at the superficial portion, while the deeper portion is fibrous (Panfili et al., 2002).

The skin is the biggest vertebrate organ and acts upon environment-individual interactions, as most information (pressure, touch, temperature) is captured by it and, in aquatic animals great part of the odorous information is processed in the skin (Junqueira and Carneiro, 2008). Therefore the integrity of this organ is responsible for maintaining animal-environment interactions, and consequently, for the welfare of the fish.

A series of authors worked with the structural organization of skin in some fish species, and the development of scales (e.g. Abraham et al., 2001; Domingues and Hayashi, 1998; Grizzle and Thiyagarajah, 1987; Fujimoto et al., 2008; Koumans and Sire, 1996; ; Langer et al., 2004; Lyng et al., 2004; Mittal and Whitear, 1979; Moss, 1972; Nolan et al., 2002; Sire and Akimenko, 2004; Sire et al., 1997; Souza and Santos, 1997; Souza et al., 2003; Souza et al., 2006; Yuan and Campana, 1998; Waterman, 2005). However, the descriptive work dates from twenty or thirty years ago and bears very little photographic record. Also, it does not focus on the scale epithelium, despite the fact that the surface is in direct contact with the water and receives and responds to a large branch of stimuli and environmental fluctuations (Souza and Santos, 1997). The present work aimed at the characterization of the scale epithelium of curimbatá, Prochilodus lineatus, once that knowledge is important for fish biology and environmental impact studies, and the area of sudy for this species has been largely overlooked.

\section{Material and Methods}

\subsection{Target species}

The target species, $P$. lineatus, comes from a Family restrained to South America and east of the Andes (Reis et al., 2003). It is a migratory species, with great biomass and economic relevance, that represents one of the major species of the Paraná river basin - Grande, Pardo and Mogi-Guaçu rivers - with wide distribution in other Brazilian basins. Although this fish suffered a reduction of population density due to anthropic impacts such as intense fishing. Therefore, the species was subject of many studies on developmental biology and population analysis (Domingues and Hayashi, 1998; Barbieri et al., 2000).

The genera of this Family (Prochilodontidae) are very important in commercial and subsistence fishing (Godoy, 1975; Reis et al., 2003) mainly on the southern basins of Brazil. Prochilodus lineatus species encompasses prophilic, rapid growth and rustic fish, what makes it suitable for stocking (Bristki, 1972).

For the histological analysis the scales were collected from individuals $P$. lineatus obtained at the ICMBio/CEPTA (21 $\left.{ }^{\circ} 55^{\prime} 35.37^{\prime \prime} \mathrm{S} / 4^{\circ} 22^{\prime} 02.023^{\prime \prime} \mathrm{O}\right)$, sampled from the Mogi Guaçu river at Pirassununga/SP between August and September of 2010 and stocked at a $350 \mathrm{~m}^{2}$ earth pond, $1 \mathrm{~m}$ deep, with enough water flow to keep the water levels, at the previously mentioned research center.

The protocols used in this research complied with those approved by the Ethics Committee on Research and Scientific Merit - UNIARARAS (646/2009) and therefore adhered to the legal requirements of Brazil.

\subsection{Histological and histochemical analysis}

Approximately 10 scales were removed with tweezers from the posterior region of the body, behind the dorsal fin, from 6 individuals. The scales were fixated on paraformaldehyde $4 \%$ or Bouin fixative for 24 hours, kept on a phosphate buffer solution for 48 hours and decalcified in EDTA $10 \%$ for 8 days. The material was dehydrated in alcohol and processed for histological techniques on historesin Leica. Sections of $7 \mu \mathrm{m}$ cut on a Leica RM 2145 microtome were mounted on slides and submitted to the following techniques: HematoxylinEosin (H.E.) for morphological analysis according to Paulete and Beçak (1976), Alcian Blue for detection of acid polysaccharides according to Junqueira and Junqueira (1983), Periodic Acid Schiff stain (PAS) for detection of neutral polysaccharides according to Junqueira and Junqueira (1983), Picrosirius Red for detection of collagen fibers I and III accoding to Pearse (1985) by polarized light, Orcein for the detection of elastin fibers according to Paulete and Beçak (1976). On the nonsectioned scales the following techniques were applied: Feulgen for detection of nuclei accoding to Paulete and Beçak (1976) and Toluidine Blue for detection of acid regions according to Junqueira and Junqueira (1983).

The slides were mounted in balsam, analyzed and photographed using a Leica DM 2000 light microscope coupled with a camera for image capturing.

\section{Results}

At the non-sectioned scales submitted to Feulgen and Toluidine Blue the presence of epithelium through the entire surface is evidenced by the marked nuclei (see Figure 1A, left side) and chromatophores (see Figure 1A, right side). These two techniques guided the study.

\subsection{General structure - H.E.}

The scales of $P$. lineatus are covered by an epidermal fold from the point of insertion in the fish's body to the end of the distal portion, on its dorsal and ventral surface. At that insertion point there is a trace of loose connective from the dermal pocket that in different preparations might not be removed along with the scale, and therefore, might not be observed (see Figure 1B - caption).

The thickness of the epithelium is irregular in both surfaces due to the ripples on the scale (see Figure 1D), on the ventral surface (inferior epithelium) it is generally thinner than on the dorsal surface (superior epithelium) (see Figure 1C). Both surfaces are thicker at the insertion 
region and the middle region of the scale (proximal region, which is a transition between the portion that is dipped on the animal's body and the exposed portion). From the middle to distal end, the multiple layers are abruptly reduced to a single layer of cells (see Figure 1B).

This thicker proximal superior epithelium (anterior to the abrupt reduction) is also differentiated (multilayered) and stratified. The cells at the basal layer are columnar and juxtaposed, meanwhile the cells at the median portion are round and turn pavement towards the superficial layer (see Figure 1C).
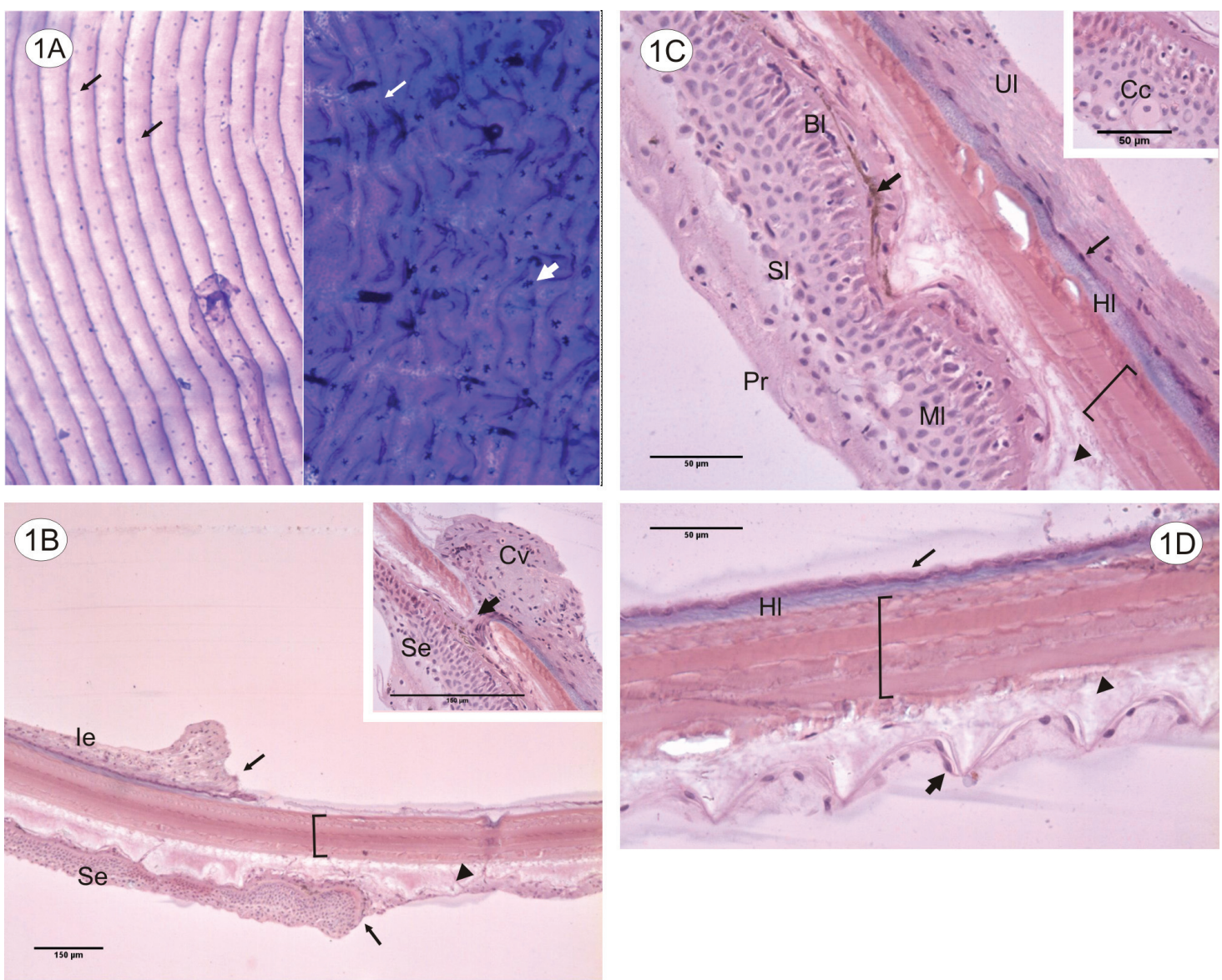

Figure 1 - A: Non-sectioned scale tested with Feulgen (left) and Toluidine Blue (right). It is noticeable the nuclei of the epithelial cells marked over the surface of the scale (thin arrow) and chromatophores (thick arrow). B: Median portion the scale submitted to the H.E. technique. It is noticeable the thickness of the epithelium before and after the point indicated by the thin arrows, where the superior epithelium (Se) is always thicker than the inferior one (Ie). The bracket indicates the collagen matrix, and its adjacent limiting layer (arrow head). At the insertion region, in the caption, notice the loose connective tissue vestige $(\mathrm{Cv})$ and the junction between the two faces of the epithelium (thick arrow) as it interrupts the collagen matrix (thick arrow). C: Proximal portion of the scale stained with H.E. Visible in this image are the multilayered superior epithelium with columnar cells at the basal layer (Bl) and chromatophores at the base (thick arrow), round cells at the median layer (Ml), that turn pavement at the superficial layer ( $\mathrm{Sl})$. Covering all the region is the peeling layer $(\mathrm{Pr})$. At the inferior epithelium, the undifferentiated tissue (Ul) and the basal layer (thin arrow). The collagen matrix (bracket) forming the scale, along with the limiting layer (arrow head) and the layer strongly marked by hematoxylin (Hl). On the caption, detail of club cell (Cc). D: Distal portion (after the abrupt reduction of the epithelium) of the scale tested with H.E. It is noticeable that there is only a single layer of cells left on the inferior epithelium (thin arrow) and on the superior epithelium, evidenced by the nucleus (thick arrow). Forming the scale, the distinct layers of the collagen matrix (bracket), the strongly marked by hematoxylin $(\mathrm{Hl})$ and the limiting layers (arrow head). The ripples along the scale are visible at the distal edge. 
Towards the distal portion of the scale the superior epithelium decreases in thickness, primarily due to a reduction of the intermediate portion. Due to an abrupt reduction the distal end of the scale is covered by a single layer of cells that accompanies the ripples (see Figure 1D).

The scale under the epithelium consists of a collagen matrix formed by distinct layers when the scale is stained by H.E. (see Figures $1 \mathrm{~B}$ and $1 \mathrm{D}$ ), together forming the basal plate and external layer, that confers consistency and shape. At the ventral surface, adjacent to the matrix there is a collagen band strongly marked by hematoxylin that accompanies the basal layer of the inferior epithelium (see Figures 1C and 1D). There is also a disorganized band over the collagen layer of the basal plate and external layer, under the superior epithelium, the limiting layer (see Figures 1B, 1C and 1D).

The superior and inferior epithelia connect on a region adjacent to the insertion point. Cells of both epidermal folds elongate towards one another and interrupt the juxtaposed collagen layers (see Figure 1B - caption). Also immediately adjacent to the insertion point a broad canal emerges amongst the collagen fibers, directed to the distal end of the scale.

\subsection{Collagen - Picrosirius Red}

The collagen is marked in red by the Picrosirius Red technique, and the stained tissue at the center of the scale is organized in what appears to be 6 different bands (see Figure 1E, left side). Under polarized light it is possible to see the predominance of collagen type III (green) at the
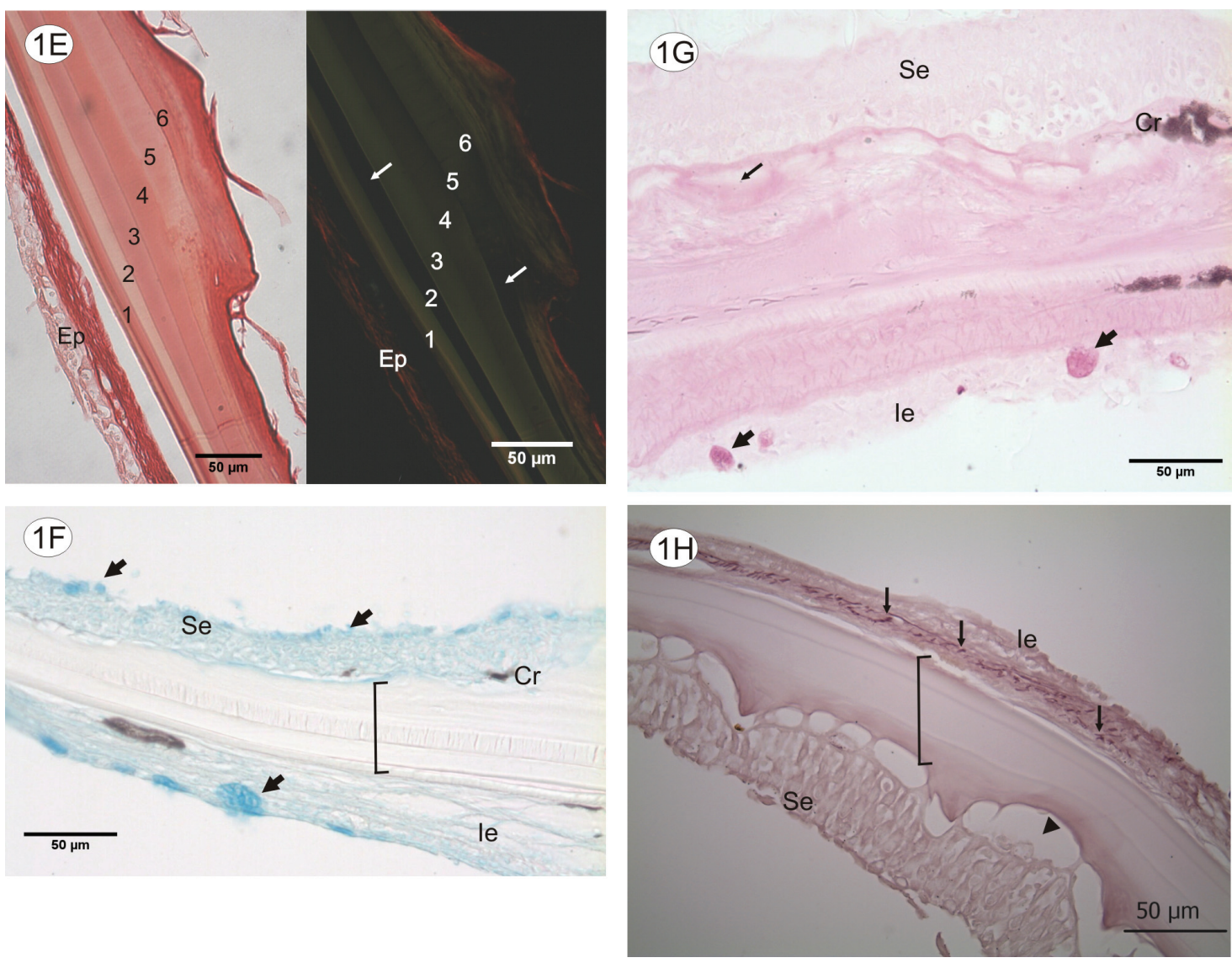

Figure 1 (cont.) - E: Scale stained with Picrosirius Red under polarized light (right) and without it (left). It is noticeable the presence of apparently six different bands of reaction at the scale matrix (numbers 1 to 6 ). In red the collagen type I at the periphery and epithelium, and collagen type III in green at the matrix. Also apparent is how a few bands did not appear under polarized light (arrow). F: Scale submitted to Alcian Blue. It is aparent the deposits of acid polysaccharides on the surface of the scale (arrow) on both faces of the epithelium, forming the glycocalyx. There are some chromatophores $(\mathrm{Cr})$ at the base of the epithelium, and the hyaline scale matrix (bracket). G: Scale tested with PAS. The markings for deposits of neutral polysaccharides are scarce (thick arrow) and also some reaction is apparent on the limiting layer (thin arrow). H: Scale submitted to Orcein. The elastic fibers marked in dark brown (arrow) at the base of the inferior epithelium (Ie). Forming the scale, the collagen matrix (bracket) and the limiting layer (arrow head). Ep = epithelium, $\mathrm{Ie}=$ inferior epithelium, $\mathrm{Se}=$ superior epithelium, $\mathrm{Cv}=$ loose connective vestige, $\mathrm{Cr}=$ chromatophore, $\mathrm{Bl}=$ basal layer, $\mathrm{Ml}=$ median layer, $\mathrm{Sl}=$ superficial layer, $\mathrm{Pr}=$ peeling region, $\mathrm{Ul}=$ undifferentiated layer, $\mathrm{Hl}=$ hematoxylin layer, $\mathrm{Cc}=$ club cell . 
center of the collagen matrix and collagen type I (red) at the periphery and epithelium (see Figure 1E- right side).

Figure 1D shows the scale composed by bands predominantly of different concentrations of collagen type III. These differences are clear when comparing the refraction indexes shown in figure $1 \mathrm{E}$. With this technique it is possible to estimate that other collagen types are present in the scale composition, a few bands are not shown with polarization for type I and III though they react to Picrosirius Red.

\subsection{Mucous - PAS and Alcian Blue}

The Alcian Blue technique marks acid polysaccharides while PAS detects neutral polysaccharides. Except for the few longitudinal regions, the collagen matrix is a hyaline structure, devoid of positive markings for both methods. Figure 1F shows many regions of the scale's superior and inferior epithelium marked by Alcian Blue, some of which are very large, composed by acid mucous layers that cover the scale.

Between the first (looser collagen) and second collagen bands, a few chromatophores are marked as well by both techniques. However, only a few regions, both in the superior and inferior surface of the scale, are PAS-positive, which indicates that the production of neutral mucous by the epithelium is extremely reduced. The limiting layer that supports the superior epithelium was also marked by the PAS technique (see Figure $1 \mathrm{G}$ ), probably because of the usual polysaccharides of the tissue.

\subsection{Elastic fibers - Orcein}

The presence of elastic fibers on the scale is evident since the technique revealed an elastic fiber net at the base of the inferior epithelium, the only portion that was marked by stain in the scale (see Figure $1 \mathrm{H}$ ).

\section{Discussion}

According to Koumans and Sire (1996) developing scales of the cichlid Hemichromis bimaculatus bear epidermis only at the outer surface. After ten days of development the scales growth is revealed by an epithelial fold around the posterior edge that shows a multilayered well-differentiated epithelium at the external surface and a two layered undifferentiated epithelium at the internal surface.

The pattern is also verified on the scales of $P$. lineatus. The superior epithelium is clearly differentiated and stratified varying from two to five layers, which is compatible to the observed by other authors (Fujimoto et al., 2008; Langer et al., 2004; Nolan et al., 2002; Souza and Santos, 1997), while the inferior epithelium is divided in two layers, the outer one, undifferentiated. However, it is important to remember that the inferior epithelium is in direct contact with the overlapping scales, which might explain why it is so thin.

Concerning the general structure, the ripples on the epithelium are most probably caused by the undulation of the scale itself (Hawkes, 1974), visible at the collagen matrix.

As for the superior epithelium, the basal and median layers of round cells with central nucleus, and the outer layer of pavement cells match the general pattern found in literature (Fujimoto et al., 2008; Langer et al., 2004; Nolan et al., 2002; Souza and Santos, 1997).

Other traits are common, such as the vestige of loose connective tissue at the insertion point of the scale, once that adjacent to the scale area inserted on the dermal poket, there is a trace of loose connective and muscular tissues (Langer et al., 2004). At the superficial layer a peeling pattern was also observed, that might correspond to a cellular renewal process of the epidermis.

According to Zaconne et al. (2001), the epidermis is a multi-function tissue, although the secretory function is dominant. Amongst these types, mucous cells marked by PAS technique are commonly found on the skin of other species of fish (Fujimoto et al., 2008; Nolan et al., 2002; Souza and Santos, 1997; Zaccone et al., 2001).

The mucous that covers the scale, like that produced by the epidermis, facilitates movement in the water and serves as a protection against pathogens, lesions (Storer et al., 2007) and adversities from the environment in general, serving as an indicator of the fish's healt (Fujimoto et al., 2008; Misra et al., 1987; Roy, 1988; Rajan and Banerjee, 1991; Storer et al., 2007), and reinforcing the protective role assigned to the scales by other authors (Coello and Khan, 1995; Domingues and Hayashi, 1998; Sauer and Watanabe, 1988).

The presence of mucous on epithelial tissue of fish is demonstrated predominately with the PAS technique (Fujimoto et al., 2008; Kilemade and Mothersill, 2000; Misra et al., 1986; Nolan et al., 2002; Roy, 1987; Rajan and Banerjee, 1991; Souza and Santos, 1997). Keeping that in mind, according to Souza and Santos (1997), the epidermis of Nile tilapia (Oreochromis niloticus) presents mucous cells in reduced number, as was verified in $P$. lineatus for neutral mucous. However, the number of acid accumulations in the scale epithelium of $P$. lineatus was higher, which made the total number of mucous cells bigger than it seemed-and indicated that the nature of the mucopolysaccharide is important for detection.

Another common differentiated cell type, other than the mucous cells, has been found, the chromatophore. These cells are generally located underlying the epidermis (Moss, 1972; Hawkes, 1974), or under overlapping scales and at the base of the dermis (Liem 1967; Hawkes, 1974). In Mugil platanus the chromatophores are found adjacent to a thick layer of melanin and confer the dark coloring of the juveniles (Langer et al., 2004), as the cells are in fact responsible for pigmentation on fish skin (Hawkes, 1974) and on the scales.

Unicellular glands are also found on the epidermis of fish, the club cells, considered epidermal secretory cells characteristic of several orders of Pisces and probably multi-purposed (Zaccone et al., 2001).

These club cells on the scale epithelium of Prochilodus lineatus are round with apparently central nucleus, 
present no reaction to routine stains and distribution along the median portion of the epithelium, as reported by other authors (Bart and Page, 1991; Berra et al., 1989; Flaxman, 1972; Halbgewachs et al., 2009; Koumans and Sire, 1995; McCormick and Larson, 2008; Stabell and Vegusdal, 2010; Strussman et al., 1994; Zaccone et al., 2001).

Amongst the functions attributed to these cells there is the production of pheromones released in response to toxic and stressing agents (Brown, 2003) and anti-pathogenic agents (Al-Hassan et al. apud Zaccone et al., 2001), which contributes to the protective role of the scale (Domingues and Hayashi, 1998). These functions suggest a potential use for scales in environmental assessment, seeing it might respond to stressing agents. It is important to highlight the advantage of using the scales for environmental assessment, since it constitutes a non-invasive technique that represents an atractive alternative to tradicional methods of assessing contamination in fish (Heltsley et al., 2005).

As for the collagen, according to Sire and Akimenko (2004), the structure of the elasmoid scale was described in many species of actinopterygians and sarcopterygians. In all of them the scales were composed by three invariable layers.

At the deeper face, the basal plate is a thick layer of incompletely mineralized tissue composed by elasmodin, that consists of a series of collagen fibrils organized into a plywood-like structure (Meunier, 1981; Schultze apud Sire and Akimenko, 2004), visible on the scales of $P$. lineatus, but not distinguishable from the adjacent layer, known as the external layer. This stratum is a thin layer of well mineralized tissue composed of a network of interlaced collagens fibrils (Sire and Akimenko, 2004).

The third layer of the scale, at the outer region, is the limiting one, that itself consists of a hyper-mineralized tissue devoid of collagen and deposited at the scale surface, close to the epidermis (Sire and Akimenko, 2004). This layer can be discriminated between the superior epithelium and the collagen matrix.

The conformation of these collagen bundles with diagonal intersections in regular pattern has been observed on the skin of elasmobranchs several years ago (Moss, 1972). However, only the different layers of collagen were found on the scale matrix, but here we demonstrate different types of collagen on the bundles.

According to Sire et al. (1997) and Sire and Akimenko (2004), the structure and organization of the limiting layer is the most variable among species. As it changes, the polysaccharide composition probably shifts, what explains the positive reaction for the studied species, not verified by other authors.

According to Moss (1972) it is in elasmobranchs that true elastic fibers are found for the first time in conjunction with the division of the dermis in a superficial layer of looser structure and a deeper compact layer of collagen. Still according to this author, the cyclostome genus Petromyzon possesses a thin network of pre-elastic fibers on the skin.
Thus the presence of elastic fibers in fish can be expected and its meaning underneath the inferior epithelium is hard to explain, though we believe it can provide flexibility to the epithelium, as it is subjected environmental adversity and physical environmental alterations, it can also help avoid breakage.

\section{Acknowledgments}

The authors are thankful to FAPESP (Fundação de Amparo à Pesquisa do Estado de São Paulo) for financial support (process number 2010/09408-4), ICMBio/CEPTA - Instituto Chico Mendes for providing the specimens used in this study and Msc. Renata Mamede da Silva Alves for kindly agreeing to revise the manuscript.

\section{References}

ABRAHAM, MY., IGER, Y. and ZHANG, L., 2001. Fine structure of the skin cells of a stenohaline freshwater fish Cyprinus carpio exposed to diluted seawater. Tissue \& Cell, vol. 33, no. 1, p. 46-54.

BARBIERI, G., SALLES, FA. and CESAROLLI, MA., 2000. Influência de fatores abióticos na reprodução do dourado, Salminus maxillosus e do curimbatá, Prochilodus lineatus do Rio Mogi Guaçu (Cachoeira de Emas, Pirassununga/SP). Acta Limnologica Brasileira, vol. 12, p. 85-91.

BART, HL. and PAGE, LM., 1991. Morphology and adaptive significance of fin knobs in egg-clustering darters. Copeia, vol. 1991, no. 1, p. 80-86.

BERRA, TM., SEVER, DM. and ALLEN, GR., 1989. Gross and histological morphology of the swimbladder and lack of accessory respiratory structures in Lepidogalaxias salamandroides, an aestivating fish from western Australia. Copeia, vol. 1989, no. 4, p. 850-856.

BRITSKI, HÁ., SATO, Y. and ROSA, ABS., 1988. Manual de identificação de peixes da região de Três Marias: (com chaves de identificação para os peixes da bacia do São Francisco). Brasília: CODEVASF. 143 p.

COELLO, WF. and KHAN, AQ., 1996. Protection against heavy metal toxicity by mucus and scales in fish. Archives of environmental contamination and toxicology, vol. 30, p. 319-326.

DOMINGUES, WM. and HAYASHI, C., 1998.Estudo experimental sobre anéis diários em escamas nas fases iniciais do desenvolvimento do curimba, Prochilodus lineatus (VALENCIENNES, 1936) (Characiformes, Prochilodontidae). Revista Brasileira de Biologia, vol. 58, no. 4, p. 609-617.

FLAXMAN, BA., 1972. Cell differentiation and its control in the vertebrate epidermis. American Zoologist, vol. 12, no. 1, p. 13-25.

FUJIMOTO, RY., CRUZ, C. and MORAES, FR., 2008. Análise de efluente e histologia da pele, fígado e rim de pacus (Piaractus mesopotamicus) suplementados com cromo trivalente. Boletim do Instituto de Pesca, vol. 34, no. 1, p.117- 124 .

GODOY, MP., 1975. Peixes do Brasil: Subordem Characoidei. Bahia: Editora e Gráfica Franciscana, 627 p. 
GRIZZLE, JM. and THIYAGARAJAH, A., 1987. Skin histology of Rivulus ocellatus marmoratus: apparent adaptation for aerial respiration. Copeia, vol. 1987, no. 1, p. 237-240.

HALBGEWACHS, CF., MARCHANT, TA., KUSCH, RC. and CHIVERS, DP., 2009. Epidermal club cells and the innate immune system of minnows. Biological Journal of the Linnean Society, vol. 98, p. 891-897.

HAWKES, JW., 1974. The structure of fish skin: the chromatophore unit. Cell and Tissue Research, vol. 149, p. 159172.

HELTSLEY, RM., COPE, WG., SHEA, G. and BRINGOLF, RB., 2005. Assessing organic contaminants in fish: Comparison of a nonlethal tissue sampling technique to mobile and stationary passive sampling devices. Environmental Science and Technology, vol. 39, no. 12, p. 7601-7608.

JUNQUEIRA, LCU. and CARNEIRO, J., 2008. Histologia Básica. $11^{\mathrm{a}}$ edição. Rio de Janeiro: Guanabara Koogan. $524 \mathrm{p}$.

JUNQUEIRA, LCU. and JUNQUEIRA LMMS., 1983. Técnicas Básicas de Citologia e Histologia. São Paulo: Livraria e Editora Santos. 123p.

KILEMADE, M. and MOTHERSILL, C., 2000. An in vitro assessment of the toxicity of 2,4-dichloroaniline using rainbow trout primary epidermal cell cultures. Environmental Toxicology and Chemistry, vol. 19, no. 8, p. 2093-2099.

KOUMANS, JTM. and SIRE, JY., 1996. An in vitro, serum-free organ culture technique for the study of development and growth of the dermal skeleton in fish. In Vitro Cellular \& Developmental Biology - Animal, vol. 32, p. 612-626.

LANGER, LS., VARGAS, VMF., FLORES-LOPES, F. and MALABARBA LR., 2004. Alterações histopatológicas na epiderme de Mugil platanus (Perciformes: Mugilidae) como resultado da ação de bactérias encontradas no rio Tramandaí, Tramandaí, RS. In Resumos do I Congresso Interamericano de Saúde Ambiental, 2004. Porto Alegre: Associação Brasileira de Engenharia Sanitária - Sessão Rio Grande do Sul. p. 20.

LIEM, KF., 1967. Functional morphology of the integumentary, respiratory, and digestive systems of the synbranchoid fish monopterus albus. Copeia, vol. 1967, no. 2, p. 375388.

LYNG, FM., LYONS-ALCANTARA, M., OLWELL, P., NÍ SHUILLEABHÁIN, S., SEYMOUR, C., COTTEL, DC. and MOTHERSILL, C., 2004. Ionizing radiation induces a stress response in primary cultures of rainbow trout skin. Radiation Research, vol. 162, no. 2, p. 226-232.

MCCORMICK, MI. and LARSON, JK., 2008. Effect of hunger on the response to, and the production of, chemical alarm cues in a coral reef fish. Animal Behaviour, vol. 75, p. 1973-1980.

MISRA, V., CHAWLA, G., KUMAR, V., LAL, H. and VISWANATHAN, PN., 1987. Effect of linear alkyl benzene sulfonate in skin of fish fingerlings (Cirrhina mrigala): Observations with scanning electron microscope. Ecotoxicology and Environmental Safety, vol. 13, p. 164168.

MITTAL, AK. and WHITEAR, M., 1979. Keratinization of fish skin with special reference of the catfish Bagarius bagarius. Cell and Tissue Research, vol. 202, p. 213-230.

MOSS, ML. 1972. The vertebrate dermis and the integumental skeleton. American Zoologist, v. 12, no. 1 p. 27-34.
NOLAN, DT., NABBEN, I., LI, J. and WENDELAAR BONGA, SE., 2002. Characterization of primary culture of rainbow trout (Oncorhynchus mykiss) skin explants: Growth, cell composition, proliferation, and apoptosis. In Vitro Cellular \& Developmental Biology - Animal, vol. 38 , no. 1 , p. $14-24$.

ORR, RT., 1988. Biologia dos Vertebrados. $5^{\mathrm{a}}$ Edição. São Paulo: Livraria Roca. 508 p.

PANFILI, J., DE PONTUAL, H., TROADEC, H. and WRIGHT. PJ., 2002. Manual of fish sclerochronology. Brest, France: Ifremer-IRD coedition. 464 p.

PAULETE, J. and BEÇAK, W., 1976. Técnicas de Citologia e Histologia. São Paulo: Livros Técnicos e Científicos. $469 \mathrm{p}$.

PEARSE, AGE., 1985. Histochemistry: Theoretical and Applied. $4^{\text {a }}$ Edição. Edinburgh: Churchill Livingstone. $1055 \mathrm{p}$.

RAJAN, MT. and BANERJEE, TK., 1991. Histopathological changes induced by acute toxicity of mercuric chloride on the epidermis of freshwater catfish - Heteropneustes fossilis (Bloch). Ecotoxicology and Environmental safety, vol. 22, p. 139-152.

REIS, RE., KULLANDER, SO. and FERRARIS, CJ., 2003. Check list of the freshwater fishes of South and Central America. Porto Alegre: EDIPUCRS. 279 p.

ROY, D., 1988. Statistical analysis of anionic detergent-induced changes in the goblet mucous cells of opercular epidermis and gill epithelium of Rita rita (Ham.) (Bagridae: Pisces). Ecotoxicology and Environmental Safety, vol. 15, p. 260271.

SAUER, GR. and WATANABE, N., 1989. Temporal and metal-specific patterns in the accumulation of heavy metals by the scales of Fundulus heteroclitus. Aquatic Toxicology, vol. 14, p. 233-248.

SIRE, JY. and AKIMENKO, MA., 2004. Scale development in fish: a review, with description of sonic hedgehog (shh) expression in the zebrafish (Danio rerio). International Journal of Developmental Biology, v. 48, p. 233-247.

SIRE, JY., ALLIZARD, F., BABIAR, O., BOURGUIGNON, J. and QUILHAC, A., 1997. Scale development in zebrafish (Danio rerio). Journal of Anatomy, vol. 190, p. 545-561.

SOUZA, MLR. and SANTOS, HSL., 1997. Análise morfológica da pele da tilápia do Nilo (Oreochromis niloticus) através da microscopia de luz. Revista Unimar, vol. 31, no. 3, p. 881- 888 .

SOUZA, MLR., DOURADO, DM., MACHADO, SD., BUCCINI, DF., JARDIM, MIA., MATIAS, R., CORREIA, C. and FERREIRA, IC., 2003. Análise da pele de três espécies de peixes: histologia, morfometria e testes de resistência. Revista Brasileira de Zootecnia, vol. 32, no. 6, p. 1551- 1559 .

SOUZA, MLR., GODOY, LC., KOZUKI, HT., CASACA, JM., DOURADO, DM.and JACINTO, MAC., 2006. Histologia da pele da carpa prateada (Hypophtalmichthys molitrix) e testes de resistência do couro. Revista Brasileira de Zootecnia, vol. 35, no. 4, p. 1265- 1272.

STABEL, OB. and VEGUSDAL, A., 2010. Socializing makes thick-skinned individuals: on the density of epidermal alarm substance cells in cyprinid fish, the crucian carp (Carassius carassius). Jounal of Comparative Physiology, vol. 196, p. 639-647. 
Alves, RMS. et al.

STORER, TI., USINGER, RL., STEBBINS, RC. and NYBAKKEN, JW., 2007. Zoologia Geral. 6ª Edição. São Paulo: Companhia Editora Nacional. 816 p.

STRUSSMAN, CA., NIN, F. and TAKASHIMA, F., 1994. Microscale variation in epidermal thickness, distribution and size of mucus and alarm substance cells in the skin of juvenile fancy carp (Cyprinus carpio). Copeia, vol. 1994, no. 4, p. 956-961.

WATERMAN, RE., 1970. Fine structure of scale development in the teleost, Brachydanio rerio. The anatomical record, vol. 168 , no. 3, p. 361-379.
YUAN, EC. and CAMPANA, M., 1998. Scale development of Prochilodus lineatus (Val.) (Pisces, Curimatidae) juveniles from the Paraná River. Revue d'Hydrobiolgie Tropicale, vol. 26, no. 4, p. 327-332.

ZACCONE, G., KAPOOR, BG., FASULO, S. and AINIS, L., 2001. Structural, histochemical and functional aspects of the epidermis of fishes. Advances in marine biology, vol. 40, p. 255-348. 